\title{
PENGARUH SENAM KAKI DIABET TERHADAP PENURUNAN KADAR GULA DARAH PADA PENDERITA DIABETES MELLITUS TYPE II
}

\author{
Nuraeni*, I Putu Dedy Arjita** \\ Fakultas Kedokteran Universitas Islam Al-Azhar \\ J1. Unizar No.20 Turida Mataram
}

\begin{abstract}
ABSTRAK
Konsensus Perkeni 2011 menyatakan bahwa terdapat 4 (empat) pilar penatalaksanaan Diabetes Mellitus (DM), yaitu : edukasi, terapi gizi medis, latihan jasmani, dan terapi farmakologis. Sebagian besar penatalaksanaan penyakit diabetes menggunakan obat, padahal obat bukan merupakan satu-satunya cara yang dapat digunakan untuk penatalaksanaan penyakit DM. Untuk penatalaksanaan penyakit DM yang telah dikenal ada 3 (tiga) cara, yaitu : mengatur makanan, olahraga, dan obat-obatan. Penatalaksaan DM sebaiknya menggunakan olahraga dan disertai dengan mengatur pola makan (Suryanto, 2009).

Tujuan penelitian ini adalah untuk mengetahui Pengaruh Senam Kaki terhadap Penurunan Kadar Gula Darah pada Penderita Diabetes Mellitus Type II di wilayah kerja Puskesmas Sape Kabupaten Bima. Penelitan ini menggunakan desain pra eksperimental dengan pendekatan pre test-post test design. Teknik pengambilan sampel menggunakan accidental sampling dengan jumlah sampel sebanyak 26 responden. Analisa Data menggunakan uji one sample t-test dengan nilai alfa 0.05 .

Berdasarkan uji t-test dengan bantuan program SPSS versi 16 diperoleh t-hitung 16,073 dengan taraf signifikansi 0,05 dan nilai df sebesar 25 masih lebih kecil dengan nilai batas kritis $\alpha=$ $0,05(0,000<0,05)$. Berdasarkan hasil ini maka dapat dinyatakan bahwa Senam Kaki berpengaruh terhadap penurunan Kadar Gula Darah pada penderita Diabetes Mellitus type II di wilayah kerja Puskesmas Sape Kabupaten Bima.

Sesuai dengan hasil penelitian diharapkan penderita mampu melakukan senam kaki secara mandiri untuk membantu mengontrol kadar gula darah selain dengan mengkonsumsi obat maupun dengan diit, sehingga dapat mengurangi komplikasi akibat peredaran darah yang buruk seperti luka lama sembuh yang berujung pada gangren.
\end{abstract}

Kata Kunci : Senam Kaki, Gula Darah, Diabetes Mellitus Tipe II.

\section{PENDAHULUAN}

Pembangunan

merupakan bagian integral dari Pembangunan Nasional. Undang-undang Nomor 23 tahun 1992 tentang Kesehatan menetapkan bahwa kesehatan adalah keadaan sejahtera dari badan, jiwa dan sosial yang memungkinkan setiap orang hidup produktif secara sosial dan ekonomi. Sedangkan dalam konstitusi World Health Organization (WHO)
sebagai Organisasi Kesehatan Sedunia
tahun 1948 disepakati bahwa
diperolehnya derajat kesehatan yang
setinggi-tingginya adalah suatu hak yang fundamental bagi setiap orang tanpa membedakan ras, agama, politik yang dianut dan tingkat sosial ekonominya.

Menurut survei yang dilakukan WHO, Indonesia menempati urutan ke-4 dengan jumlah penderita diabetes mellitus (DM) terbesar di dunia setelah India, Cina dan Amerika Serikat.

Prevalensi 8,6 \% dari total penduduk, diperkirakan pada tahun 1995 terdapat 4,5 juta pengidap diabetes mellitus dan pada tahun 2025 diperkirakan meningkat menjadi 12,4 juta penderita, sedangkan data Depkes menunjukkan jumlah pasien diabetes 
mellitus rawat inap maupun rawat jalan di rumah sakit menempati urutan pertama dari seluruh penyakit endokrin (Depkes, 2010).

Menurut Fransisca (2012) bahwa meningkatnya kejadian DM di negaranegara tersebut termasuk Indonesia akibat dari peningkatan kemakmuran di negaranegara ini disertai perubahan pola hidup terutama di kota-kota besar.

Fenomena peningkatan jumlah penderita DM ini juga dialami oleh negara negara maju lainnya 40 - 50 tahun yang lalu saat mereka mulai mengalami kemajuan ekonomi yang cukup pesat bahkan ahli metabolik Jerman, Menhert mengistilahkannya sebagai "Wohlstands syndrome" ("sindroma kemakmuran") (Fransisca, 2012).

Menurut ADA (American Diabetes Association) tahun 2010 DM merupakan suatu kelompok penyakit metabolik dengan karakteristik hiperglikemia yang terjadi karena kelainan sekresi insulin, kerja insulin atau kedua-duanya.

Berdasarkan klasifikasi WHO, DM terbagi atas beberapa tipe yaitu : DM tipe I, DM tipe II, diabetes gestasional dan diabetes tipe lainnya. Diabetes melitus tipe II merupakan jenis DM yang paling banyak diderita masyarakat. Karena dari semua kasus DM pada populasi di beberapa negara diketahui bahwa sekitar 90\% adalah DM tipe II. Peningkatan ini umumnya terjadi di negara-negara berkembang disebabkan karena pertumbuhan penduduk, proses penuaan, obesitas, diet serta pola hidup yang tidak sehat (Nanik 2012).

DM tipe II dimulai pada dewasa pertengahan (40-50 tahun). Sedangkan berdasarkan analisis data Riskesdas tahun 2007 yang dilakukan oleh Irawan, didapatkan bahwa prevalensi DM tertinggi terjadi pada kelompok umur di atas 45 tahun sebesar 12,41\% (Shara, 2013).

Menurut Konsensus Perkeni 2011, ada 4 (empat) pilar penatalaksanaan DM, yaitu : edukasi, terapi gizi medis, latihan jasmani, dan terapi farmakologis. Di Indonesia, ternyata sebagian besar penatalaksanaan penyakit diabetes menggunakan obat, padahal obat bukan merupakan satu-satunya cara yang dapat digunakan untuk penatalaksanaan penyakit DM. Untuk penatalaksanaan penyakit DM yang telah dikenal ada 3 (tiga) cara, yaitu : mengatur makanan, olahraga, dan obat-obatan.

Penatalaksaan DM sebaiknya menggunakan olahraga dan disertai dengan mengatur pola makan (Suryanto, 2009). Selanjutnya Santoso (2008) dalam Suryanto (2009) menyatakan bahwa olahraga yang dianjurkan untuk penderita diabetes mellitus adalah aerobic low impact dan rithmis, misalnya berenang, jogging, naik sepeda, dan senam. Sedangkan latihan resisten statis tidak 
dianjurkan (misalnya olah raga beban angkat besi dan lain sebagainya).

Tujuan latihan adalah untuk meningkatkan kesegaran jasmani atau nilai aerobic optimal. Menurut Brunner \& Suddart (2001) latihan sangat penting dalam penatalaksanaan DM karena efeknya dapat menurunkan kadar glukosa darah dan mengurangi faktor resiko kardiovaskuler. Latihan akan menurunkan kadar glukosa darah dengan meningkatkan pengambilan glukosa oleh otot dan memperbaiki pemakainan insulin.

Setiawan (2011) mengatakan salah satu aktifitas fisik yang juga dianjurkan untuk dilakukan secara rutin oleh pasien DM adalah gerakan senam kaki diabetikum.

Berdasarkan laporan tahun 2007, prevalensi DM di NTB sebesar 77.265 $(1,8 \%)$ dari jumlah total penduduk sebanyak 2.213.275 jiwa. NTB merupakan salah satu provinsi dari 17 provinsi yang mempunyai prevalensi penyakit DM di atas Prevalensi Nasional yaitu : $1,1 \%$ berdasarkan diagnosis kesehatan dan gejala (Riskesdas, 2007). Puskesmas Sape Kabupaten Bima menerima pasien DM. Penyakit DM menempati urutan ke dua terbanyak setelah hipertensi, dimana pasien rawat jalan yaitu : 1.510 orang atau 15,2\% (Jurnal Gizi Prima, 2011).
Berdasarkan data yang diperoleh dari Puskesmas Sape Kabupaten Bima didapatkan jumlah klien DM tipe II yang menjalani rawat jalan periode Agustus 2014 sebanyak 26 orang, dimana setiap harinya terdapat kira-kira 7 kunjungan. Penatalaksanaan yang diberikan pihak Puskesmas Sape Kabupaten Bima berupa obat-obatan dan insulin, sedangkan untuk aktifitas fisik seperti senam kaki belum pernah diterapkan.

Fenomena yang sering terjadi pada penderita DM di wilayah kerja Puskesmas Sape Kabupaten Bima yaitu : penderita DM dalam sehari-hari sering mengabaikan perilaku kesehatan seperti melakukan senam DM. Hal ini terjadi karena kurangnya pengetahuan tentang senam DM dan petugas belum pernah melakukan penyuluhan tentang senam kaki kepada pasien maupun keluarga pasien sehingga pasien tidak pernah tahu manfaat dari senam kaki untuk menjaga kestabilan kadar gula darah. Menarik untuk dikaji tentang pengaruh senam kaki diabet terhadap penurunan kadar gula darah pada penderita diabetes mellitus type II atau NIDDM di Wilayah Kerja Puskesmas Sape, dengan harapan dapat memperoleh pengetahuan baru yang dapat digunakan sebagai dasar untuk mengelola penderita diabetes mellitus type II dalam mengendalikan kadar gula darahnya. 


\section{METODE}

Populasi penelitian ini adalah semua penderita DM di wilayah kerja Puskesmas Sape Kabupaten Bima yang berjumlah 26 orang. Sebanyak 26 orang dipergunakan sebagai sampel dengan teknik sampling Total Sampling.

Penelitian dilaksanakan menggunakan pre-experimental design dengan rancangan one group pre-test-post test design (Alimul, 2003), dimana setiap sampel yang diambil akan diberikan pretest dahulu sebelum diberikan intervensi, kemudian setelah diberikan intervensi selanjutnya dilakukan post- test untuk mengetahui penurunan kadar glukosa darah (Nursalam, 2008).

Beberapa hal yang perlu didefinisikan secara operasional merupakan batasan variabel yang dimaksud, atau tentang apa yang diukur oleh variabel yang bersangkutan (Notoatmodjo, 2012) diantaranya adalah Senam Kaki yaitu suatu kegiatan atau latihan fisik yang dilakukan oleh klien DM dengan teknik menggerakkan kaki untuk mengontrol kadar gula darah; perubahan kadar gula darah yaitu status atau keadaan dari glukosa dalam darah yang diukur sebelum dan sesudah diberikan senam kaki; dan diabetes mellitus yaitu suatu penyakit metabolik dengan karakteristik hiperglikemia yang terjadi karena kelainan sekresi insulin, kerja insulin atau kedua-duanya.

Teknik pengumpulan data dilakukan menggunakan instrumen berupa pedoman wawancara dan pedoman observasi untuk mencari perubahan atau hal-hal yang akan diteliti, dimana observasi merupakan suatu hasil perbuatan jiwa secara aktif dan penuh perhatian untuk menyadari adanya rangsangan (Notoatmodjo, 2010). Data yang dikumpulkan selanjutnya dianalisis statistik komparartif menggunakan uji statistik $t$-test dengan taraf signifikan 0,05 dengan software SPSS for Window.

\section{HASIL DAN PEMBAHASAN}

\section{Hasil}

Tabel 1. Distribusi Responden berdasarkan Umur Pasien Diabetes Mellitus

\begin{tabular}{|c|c|c|c|}
\hline No. & Umur (tahun) & Frekuensi (f) & Prosentase (\%) \\
\hline 1. & $17-25$ & 1 & 3.8 \\
\hline 2. & $26-35$ & 2 & 7.7 \\
\hline 3. & $36-45$ & 5 & 19.2 \\
\hline 4. & $46-55$ & 12 & 46.2 \\
\hline 5 & $56-65$ & 6 & 23.1 \\
\hline & Total & 26 & 100.0 \\
\hline
\end{tabular}


Tabel 2. Distribusi Responden berdasarkan Jenis Kelamin Pasien Diabetes Mellitus

\begin{tabular}{|c|c|c|c|}
\hline No. & ב Jenis Kelamin & Frekuensi (f) & Prosentase (\%) \\
\hline 1. & Laki-Laki & 10 & 38.5 \\
\hline 2. & Perempuan & 16 & 61.5 \\
\hline & Total & 26 & 100.0 \\
\hline
\end{tabular}

Tabel 3. Distribusi Responden Berdasarkan Kadar Gula Darah Sebelum Pelaksanaan Senam Kaki.

\begin{tabular}{|c|c|r|r|}
\hline \hline No. & $\begin{array}{c}\text { Kadar Gula } \\
\text { Sebelum }\end{array}$ & Frekuensi (f) & Prosentase (\%) \\
\hline 1. & $80-144 \mathrm{mg} / \mathrm{dl}$ & 0 & 0 \\
\hline 2. & $145-179 \mathrm{mg} / \mathrm{dl}$ & 0 & 0 \\
\hline 3. & $\geq 180 \mathrm{mg} / \mathrm{dl}$ & 26 & 100.0 \\
\hline \multicolumn{2}{|r|}{ Total } & 26 & 100.0 \\
\hline \hline
\end{tabular}

Tabel 4. Distribusi Responden Berdasarkan Kadar Gula Darah Sesudah Pelaksanaan Senam Kaki.

\begin{tabular}{|c|c|r|r|}
\hline \hline No. & $\begin{array}{c}\text { Kadar Gula } \\
\text { Sesudah }\end{array}$ & Frekuensi (f) & Prosentase (\%) \\
\hline 1. & $80-144 \mathrm{mg} / \mathrm{dl}$ & 14 & 53,8 \\
\hline 2. & $145-179 \mathrm{mg} / \mathrm{dl}$ & 12 & 46,2 \\
\hline 3. & $\geq 180 \mathrm{mg} / \mathrm{dl}$ & 0 & 0 \\
\hline \multicolumn{2}{r|}{ Total } & 26 & 100.0 \\
\hline
\end{tabular}

Tabel 5. Hasil Uji Statistik One Sample t-test

\begin{tabular}{|c|c|c|c|}
\hline \hline \multicolumn{4}{|c|}{ One-Sample Test } \\
\hline & $t$ & $d f$ & Sig. (2-tailed) \\
\hline Beda & 16.073 & 25 & .000 \\
\hline
\end{tabular}

Berdasarkan hasil uji statistik dengan menggunakan uji One Sample ttest diperoleh bahwa nilai t-hitung sebesar 16,073 dengan taraf signifikansi 0,00 dan nilai $d f$ sebesar 25 diketahui nilai t-tabel sebesar 2,060 dengan nilai signifikansi sebesar 0,05. Hal ini menunjukkan $\mathrm{H}_{0}$ ditolak dan dapat dinyatakan bahwa senam kaki berpengaruh terhadap penurunan kadar gula darah pada penderita diabetes mellitus tipe II di wilayah kerja Puskesmas Sape Kabupaten Bima.

\section{Pembahasan}

Kadar Gula Penderita Diabetes Mellitus Tipe II Sebelum Pelaksanaan Senam Kaki

Tabel 3 menunjukkan bahwa semua responden sejumlah 26 orang memiliki kadar gula darah $\geq 180 \mathrm{mg} / \mathrm{dl}$. Kontrol gula darah pada pasien diabeletes mellitus tipe II sebelum diberikan senam kaki kurang baik.

Berdasarkan informasi yang diperoleh dari pasien dapat diketahui bahwa pasien belum pernah melakukan 
senam kaki dalam menjaga kadar gula darahnya. Hal yang dilakukan hanyalah menjaga diit makan dan selalu mengkonsumsi obat pengatur gula darah sebelum dan sesudah makan.

Setiap responden memiliki kemampuan tubuh yang berbeda-beda untuk melakukan kontrol terhadap kadar gula darahnya, dapat bergantung dari jenis diit yang dilakukan, gaya hidup yang dijalani, penyakit penyerta dan usia pasien.

Hasil penelitian menunjukkan data bahwa semua pasien sebelum diberikan senam kaki memiliki rentang kadar gula darah terendah $180 \mathrm{mg} / \mathrm{dl}$ dan rentang kadar gula darah tertinggi $>482 \mathrm{mg} / \mathrm{dl}$, dimana hal ini dapat diartikan bahwa diit yang dilakukan bersama dengan obat pengatur gula darah yang dikonsumsi oleh pasien belum menunjukkan perubahan yang cukup berarti pada kadar gula darah pasien. Diit yang paling sering dilakukan oleh pasien adalah mengurangi konsumsi nasi putih dan gula, tetapi pasien tetap mengkonsumsi buah-buahan sebagai camilannya. Buah yang dikonsumsi tidak dipilih jenisnya oleh pasien dan jumlah buah yang dikonsumsi juga tidak dibatasi, hal ini memungkinkan pasien tersebut tetap memiliki gula darah yang tetap tinggi meskipun sudah melakukan diit dan minum obat pengontrol gula darah.
Gula darah adalah produk akhir dan merupakan sumber energi utama organisme hidup yang kegunaannya dikontrol oleh insulin. Umumnya tingkat gula darah bertahan pada batas batas yang sempit sepanjang hari 4 - $8 \mathrm{mmol} / \mathrm{l}$ (70 $150 \mathrm{mg} / \mathrm{dl}$ ). Tingkat ini meningkat setelah makan dan biasanya berada pada level terendah pada pagi hari, sebelum orang makan.

Pasien diabetes mellitus adalah penyakit yang paling menonjol yang disebabkan oleh gagalnya pengaturan kadar glukosa darah. Selain glukosa, kita juga menemukan jenis-jenis gula lainnya, seperti fruktosa dan galaktosa. Diabetes mellitus khususnya tipe 2 atau diabetes mellitus tidak tergantung insulin merupakan diabetes yang disebabkan sebagai akibat dari pola hidup yang tidak sehat sehinga tubuh mengalami gangguan pada fungsinya khususnya pada pankreas yang bertugas sebagai pengatur kadar gula darah.

Diabetes Mellitus merupakan kelompok penyakit metabolik dengan karakteristik hiperglikemia yang terjadi karena kelainan sekresi insulin, kerja insulin atau kedua duanya (Purnamasari, 2009).

Diabetes Mellitus tipe II adalah jenis yang paling sering dijumpai. Biasanya terjadi pada usia di atas 40 tahun, tetapi bisa pula timbul pada usia di atas 20 tahun. Sekitar $90-95 \%$ 
penderita DM adalah penderita DM tipe II. DM resisten, lebih sering pada dewasa, tapi dapat terjadi pada semua umur. Kebanyakan pederita kelebihan berat badan, ada kecendrungan familiar (Riyadi, 2008).

Faktor resiko DM adalah pola makan. Makan secara berlebihan dan melebihi jumlah kadar kalori yang dibutuhkan oleh tubuh dapat memicu timbulnya DM, karena pancreas mempunyai kapasitas tertentu untuk memproduksi jumlah atau kadar insulin. Oleh karena itu, mengkonsumsi makanan secara berlebihan dan tidak diimbangi oleh sekresi insulin dalam jumlah memadai dapat menyebabkan kadar gula dalam darah meningkat dan menyebabkan diabetes mellitus. Gaya hidup, dimana makanan cepat saji dan olahraga tidak teratur merupakan salah satu pemicu terjadinya diabetes mellitus (Riyadi, 2008).

\section{Kadar Gula Penderita Diabetes}

Mellitus Tipe II Sesudah Pelaksanaan Senam Kaki

Berdasarkan tabel 4 dapat diketahui bahwa sebagian besar responden memiliki kadar gula darah 80 - 144 mg/dl sebanyak 14 orang $(53,8 \%)$ dan $145-179 \mathrm{mg} / \mathrm{dl}$ sebanyak 12 orang (46,2\%). Data menunjukkan bahwa semua responden yang melaksanakan senam kaki mengalami penurunan kadar gula darah.
Penurunan kadar gula darah ada yang mencapai nilai normal meskipun ada juga beberapa pasien yang mengalami penurunan kadar gula darah tetapi masih belum berada pada rentang nilai normal.

Senam kaki diberikan selama 3 (tiga) hari, pasien tetap diperbolehkan melakukan diit dan mengkonsumsi obat pengontrol gula darah seperti yang dilakukan sebelum melaksanakan senam kaki. Pengukuran kadar gula darah dilakukan setelah pelaksanaan senam kaki selama tiga hari berturut-turut. Senam kaki dilakukan pagi dan sore hari, sementara pengukuran kadar gula darah dilakukan sebanyak 2 (dua) kali, yaitu : satu kali sebelum pelaksanaan senam kaki dan 1 (satu) kali pada 2 jam setelah latihan senam kaki dilakukan oleh pasien pada hari ke 3 pelaksanaan senam kaki.

Pasien DM yang melaksanakan senam kaki merupakan pasien tanpa komplikasi gangren. Senam kaki dilakukan selama 15 menit, sebanyak 2 (dua) kali dalam sehari. Berdasarkan informasi dari pasien diketahui bahwa setelah melaksanakan senam kaki, mereka merasa lebih segar dan merasakan badan lebih fit serta rasa kesemutan dikaki berkurang.

Kadar gula darah dapat dikontrol dengan 3 (tiga) cara yaitu menjaga berat badan ideal, diet makanan seimbang dan melakukan olahraga atau latihan fisik. Kegiatan jasmani sehari hari dan latihan 
jasmani secara teratur (3 - 4 kali seminggu selama kurang lebih 30 menit), merupakan salah satu pilar dalam pengelolaan diabetes mellitus.

Kegiatan sehari hari seperti berjalan kaki ke pasar, menggunakan tangga, berkebun harus tetap dilakukan. Latihan jasmani selain untuk menjaga kebugaran juga dapat menurunkan berat badan dan memperbaiki sensitivitas insulin, sehingga akan memperbaiki kendali glukosa darah.

Latihan jasmani yang dianjurkan berupa latihan jasmani yang bersifat aerobik seperti jalan kaki, bersepeda santai, jogging, dan berenang. Latihan jasmani sebaiknya disesuaikan dengan umur dan status kesegaran jasmani. Untuk mereka yang relatif sehat, intensitas letihan jasmani bisa ditingkatkan, sementara yang sudah mendapat komplikasi dapat dikurangi.

Santoso (2008) dalam Suryanto (2009) menyatakan bahwa olahraga yang dianjurkan untuk penderita diabetes mellitus adalah aerobic low impact dan rithmis, misalnya berenang, jogging, naik sepeda, dan senam. Sedangkan latihan resisten statistik tidak dianjurkan (misalnya olahraga beban angkat besi dan lain-lain). Tujuan latihan adalah untuk meningkatkan kesegaran jasmani atau nilai aerobik optimal.

\section{Pengaruh Senam Kaki terhadap Penurunan Kadar Gula Darah pada Penderita Diabetes Mellitus Tipe II}

Berdasarkan hasil uji statitistik dengan menggunakan uji One Sample ttest diperoleh nilai t-hitung sebesar 16,073 dengan taraf signifikansi 0,00 dan nilai $d f$ sebesar 25 diketahui nilai t-tabel sebesar 2,060 dengan nilai signifikansi sebesar 0,05. Hal ini menunjukkan $\mathrm{H}_{0}$ ditolak, sehingga dapat dinyatakan bahwa senam kaki mempengaruhi penurunan kadar gula darah pada penderita diabetes mellitus tipe II di wilayah kerja Puskesmas Sape Kabupaten Bima.

Senam kaki dapat mempengaruhi penurunan kadar glukosa darah karena senam kaki melalui kegiatan atau latihan gerakan yang dilakukan oleh pasien diabetes mellitus membantu melancarkan peredaran darah bagian kaki, memperbaiki sirkulasi darah dan memperkuat otot-otot dan mencegah terjadinya kelainan bentuk kaki. Selain itu dapat meningkatkan kekuatan otot betis, otot paha, dan juga mengatasi keterbatasan pergerakan sendi (Ibrahim, 2012).

Gerakan senam kaki sangatlah mudah untuk dilakukan (dapat dalam atau di luar ruangan) dan tidak memerlukan waktu yang lama (hanya sekitar 15-30 menit) serta tidak memerlukan peralatan yang rumit (kursi dan sehelai koran bekas). Minimal gerakan senam kaki 
dilakukan 3 (tiga) kali seminggu, namun akan lebih baik jika dilakukan setiap hari. Melakukan senam kaki secara teratur dapat membantu pasien diabetes mellitus mengatur kadar glukosa darahnya dalam rentang normal dan stabil.

Mekanisme perubahan (penurunan) kadar gluksa darah setelah melakukan senam kaki disebabkan oleh perubahan metabolik yang dipengaruhi oleh lama latihan, berat latihan, tingkatan kadar insulin plasma, kadar gula darah, kadar keton, dan imbangan cairan tubuh. Pada saat senam kaki tubuh memerlukan energi, sehingga pada otot yang tadinya tidak aktif menjadi aktif, karena terjadi peningkatan kebutuhan glukosa. Kepekaan ini akan berlangsung lama, bahkan hingga latihan telah berakhir. Pada latihan jasmani akan terjadi peningkatan aliran darah, menyebabkan lebih banyak tersedia reseptor insulin dan reseptor menjadi lebih aktif sehingga terjadi peningkatan pemakaian glukosa oleh otot yang aktif yang pada gilirannya akan mempengaruhi penurunan kadar glukosa darah (Santoso, 2008).

\section{PENUTUP}

\section{Simpulan}

Berdasarkan analisa data dan pembahasan hasil penelitian, maka dapat disimpulkan sebagai berikut :
1. Seluruh responden sebelum pelaksanaan Senam Kaki
memiliki

kadar gula darah $\geq 180$ $\mathrm{mg} / \mathrm{dl}$ sebanyak 26 orang (100\%).

2. Sebagian besar responden setelah pelaksanaan senam kaki memiliki kadar gula darah $80-144$ mg/dl sebanyak 14 orang $(53,8 \%)$ dan 145 $179 \mathrm{mg} / \mathrm{dl}$ sebanyak 12 orang $(46,2$ $\%)$.

3. Hasil analisis menunjukkan bahwa senam kaki mempengaruhi penurunan kadar gula darah pada penderita diabetes mellitus tipe II.

\section{Saran}

Perlu ada penelitian lebih lanjut tentang bagaimana durasi dan frekuensi pelaksanaan senam kaki, termasuk variasi gerakan serta besar pengaruhnya terhadap skala penurunan kadar gula darah penderita diabetes mellitus tipe II dengan jumlah sampel yang memadai dan representatif.

\section{DAFTAR PUSTAKA}

Arifin, Zaenal. 2011. Analisis Hubungan Kualitas Tidur Dengan Kadar Glukosa Darah Pasien Diabetes Mellitus Tipe 2 di Rumah Sakit Umum Propinsi Nusa Tenggara Barat, Tesis. Jakarta: Universitas Indonesia.

Anonim.2011. gula darah, glukosa, diabetes mellitus (online). (http://id.wikipedia.org diunduh tanggal 20 januari 2013)

Bintanah S. dan handarsari E.2010. asupan serat dengan kadar gula darah,kadar kolesterol total dan status gizi pada pasien diabetes 
mellitus tipe 2 di rumah sakit roemani semarang LPPM UNIMUS

Departemen Kesehatan RI. (2003). Indiaktor Indonesia sehat 2010 dan pedoman penetapan indikator provinsi sehat dan kabupaten atau kota sehat: Jakarta

Depkes RI. (2003). Indonesia sehat 2010. Jakarta: Departemen Kesehatan RI

Ibrahim,Z.S. 2012. Pengaruh Senam Kaki Terhadap Peningkatan Sirkulasi Darah Kaki Pada Pasien Diabetes Mellitus Tipe II di RSUP Fatmawati Jakarta

Ilyas, E.2009. Penatalaksanaan diabetes mellitus terpadu. Jakarta:FKUI

Jauhari, Kurniawan. 2013. Pengaruh Senam Kaki Terhadap Perubahan Kadar Glukosa Darah Pada Lansia Dengan Diabetes Mellitus Di Desa Rumbuk Kecamatan Sakra Lombok Timur, Skripsi

Meydani, P.Y.D. 2011 faktor-faktor yang berhubungan dengan upaya pencegahan kompilkasi DM oleh pasien DM di poli klinik khusus penyakit dalam RSUP. DR. M.DJAMIL padang. Program studi ilmu keperawtan Universitas andalas.

Nursalam. 2008. Konsep dan penerapan metodologi penelitian ilmu keperawtan: pedoman skripsi,tesis dan Instrumen penelitian keperawtan. Edisi 2. Jakarta: salemba medika

Santoso M. 2008. Senam Diabetes Indonesia Seri 4. Jakarta : Persatuan
Setiawan, Yahmi. 2011. Senam Kaki Untuk Penderita Diabetes Mellitus. Layanan Kesehatan Cuma-Cuma

Setiadi. (2007). Konsep dan penulisan riset keperawatan. Yogyakarta : PT. Graha Ilmu.

Shara Kurnia Trisnawati. 2012. Faktor Risiko Kejadian Diabetes Melitus Tipe II Di Puskesmas Kecamatan Cengkareng Jakarta Barat Tahun 2012, Jurnal.

STIKES Mataram. 2010. Buku Pedoman Penulisan Skripsi. Mataram : Tim STIKES Mataram

Sudoyo. (2007). Ilmu penyakit dalam. Jakarta:FKUI

Sugiyono. 2010. Statistika Untuk Penenlitian. Bandung: Alfa Beta

Suryanto. 2009. Peran olahraga senam diabetes mellitus Indonesia bagi penderita diabetes mellitus. Pendidikan kesehatan dan reakrasi FIK UNY

Sustrani, dkk. (2006). Senam diabetes mellitus. Jakarta: PT Gramedia Pustaka Utama

Tandra Hans. (2008). Diabetes. Jakarta: PT Gramedia Pustaka Utama

PERKENI.(2006). Konsesus pengelolaan dan pencegahan diabetes mellitus tipe 2 di Indonesia. Jakarta:Perkumpulan Endokrinologi Indonesia 